\title{
JOURNAL.RU
}

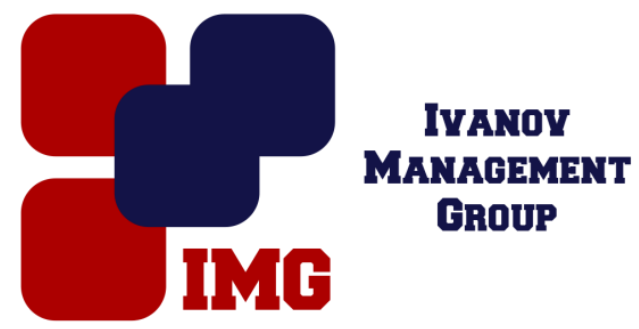

Зяблова Т.Е., Левицкая Э.А.

Владимирский юридический институт ФСИН РФ Владимир, Россия

doi: $10.18411 / 1 \mathrm{j}-31-07-2017-42$

idsp 000001:1j-31-07-2017-42

\section{Аксиомы революционного правотворчества}

\section{Аннотация}

Содержание статьи охватывает две проблемные сферы теории государства и права: теорию правотворчества и правовые аксиомы. В процессе исследования научной и учебной литературы, посвященной становлению советского права, раскрывается природа и специфические черты аксиом юридической науки. Проводится идентификация положений о замене старого права новым в ходе революций и о сущности революционного законотворчества на соответствие правовым аксиомам.

Ключевые слова: аксиомы, аксиомы науки права, законы свергнутых правительств, нормативно-правовые акты, правотворчество, постулаты, правопонимание, революция.

\section{Аксиомы революционного правотворчества}

Вопрос об аксиомах революционного правотворчества возник на пересечении возросшего в связи со столетием октябрьских событий 1917 г. интереса к различным аспектам революционной тематики, с одной стороны, и попытки проанализировать некоторые, считающиеся общепринятыми положения о закономерных изменениях, происходящих в государственноправовой сфере в ходе революции и непосредственно после нее.

Значение изучения законотворческой деятельности как важнейшего вида деятельности любого государства, многократно возрастает при исследовании ее особенностей в переходные периоды, когда начинает реализоваться и 
корректироваться существовавшее ранее только в программной форме общее представление о сущности нового (желаемого) права, его основных идеях, принципах, закладываются базовые ориентиры на его будущее развитие.

В связи с этим обращение к правотворчеству революционного периода позволяет не только удовлетворить познавательные потребности, но и помочь в решении ряда исследовательских задач. В частности, в теоретико-правовом отношении данная тема представляет интерес для дальнейшей разработки теории аксиом в праве. С точки зрения науки истории государства и права исследование аксиом правотворчества позволяет выявлять, по словам Бермана, «определенные модели и повторяющиеся черты», необходимые для построения концепций революции и, возможно, ее общей теории.

Анализ правотворческих аксиом периода революций актуален в дидактическом отношении. $\mathrm{K}$ сожалению, при изложении материала о правотворчестве в период революций в учебной литературе, как правило, даже в минимальной степени не учитывается аналитический и теоретический компонент. Преобладает стиль «хроники событий», подразумевающий в части законодательной деятельности перечисление нормативно-правовых актов и их краткое содержание, что не позволяет обучающимся создать целостное представление о особенностях деятельности по изданию нормативно-правовых актов в период революций, отличающих их от законотворческой деятельности в период «спокойного» существования государства. В свою очередь выводы по данному вопросу могут иметь значение для принятия решения о законности и легитимности новой власти. Более того, в рамках темы становления основ советского права (законодательства), изучаемой в курсе «Истории государства и права России», в большинстве учебных пособий на законодательство периода революции обращается сравнительно мало внимания, что не позволяет в полной мере оценить его значение для развития советского права, проследить наличие (или отсутствие) преемственности, ограничиваясь фразой о том, что первые акты советской власти заложили основу советского (нового) права. Обозначая в качестве цели получение представления об особенностях становления советского государства и права, многие авторы учебных пособий ограничиваются кратким пересказом содержания первых декретов советской власти, не делая каких-либо обобщений.

Тем не менее, в российской историко-правовой науке существуют некоторые общепринятые базовые представления о сущности и содержании процесса становлению советского права. Так, бесспорно аксиоматичным 
является представление о том, что революция приводит к отмене старого и созданию нового (по отношению к предшествующему) права; при этом подразумевается непригодность «старого права», сознательный отказ от него. Этот постулат созвучен мысли Г. Дж. Бермана о том, что: «Каждая из великих революций создавала новое право, каждая из них переделывала существующий правовой порядок». Применительно к российской истории в учебной литературе советского периода встречаются, например, такая формулировка: «В ходе Октябрьской социалистической революции старое, буржуазное право, выражавшее волю эксплуататорских классов и закреплявшее эксплуатацию человека человеком, было до основания разрушено. Вместо него создается новый, высший тип права - советское социалистическое право, коренным образом отличающееся от эксплуататорских типов права. Советское право с первых же дней своего существования выражало волю рабочего класса и руководимых им трудящихся масс, являлось важнейшим средством осуществления политики Советской власти, орудием борьбы с эксплуататорскими классами и мощным рычагом строительства социализма в нашей стране».

В учебной литературе последних лет акцент на «сломе буржуазного государства в процессе которого создается новое право уже не делается. Так, например, в учебном пособии С.С. Згоржельская нейтрально отмечается то, что «процесс создания советского права начинается с первых дней существования советской власти; высказываний по поводу соотношения «старого» и «нового» права нет.

Ясно, что высказывание по поводу того, что старое буржуазное право до основание разрушено в ходе Октябрьской революции, не является буквальным, т.к. говорить о создании нового права в ходе революции и даже в первые годы после нее можно с большой долей условности. Так, например, применительно к аксиоме о непременной замене «старого» права «новым» в период революции следует отметить, что «новое» государство не могло сразу создать стройную систему права. Несмотря на провозглашение нового права, «старое» продолжало действовать, т.к. не могло быть полностью отменено в одночасье. В учебной литературе в разной формулировке транслируется мысль о том. что нет одного акта, которым бы упразднялась вся система нормативных актов царской России. Работа по установлению дореволюционных актов, утративших значение, или продолжавших действовать в условиях Советского государства, проводилась до 
конца 1918 г. СНК принял более 20 нормативных правовых актов, вносящих коррективы в дореволюционное законодательство.

Тезис П. Стучки о том, что после пролетарской революции все законы свергнутых правительств считаются отмененными, в действительности касался только судебных органов и их деятельности по рассмотрению гражданских и уголовных дел и то с исключениями. На практике дореволюционное законодательство продолжало действовать, ликвидируя пробелы советского законодательства.

Таким образом, на первый взгляд, общее положение о замене старого права новым не является непреложной истиной, т.к. не находит буквального подтверждения (новое право не возникает сразу, а формируется в течении нескольких лет), что провоцирует вопрос о его аксиоматическом статусе. Однако, идентифицируя правовые явления с точки зрения отнесения их к аксиомам, следует учитывать, что правовые аксиомы не тождественны аксиомам в их строго научном математическом значении. Это - сложный, многоаспектный феномен, обнаруживающий себя в различных проявлениях. В данном случае мы имеем дело с такой разновидностью аксиом как аксиомы науки права, сомнения в которых, в отличие от аксиом логики, математики и физики, возможны, и вызываются они их своеобразием. Строго говоря, в отношении гуманитарных наук, рассуждать об аксиомах можно только, если принимать их таковыми в переносном смысле. Прав Л.М. Лопатин, утверждая: «дело не в том, как мы назовем рассмотренные истины - аксиомами, законами разума или еще какнибудь». Аксиомы науки права, как и аксиомы других наук - всегда предположения; все они истинны лишь в той или иной степени; они не самоочевидны, т.е. не явлены непосредственно, как законы природы. Выявление и формулировка аксиом, наделение их непосредственной убедительностью требует определенных творчески-интеллектуальных усилий исследователей.

В этом смысле положение о замене права в связи с революционными преобразованиями является аксиоматичным, поскольку отражает сущностные качества права, логику его развития, а также выступает в качестве ступени философско-логического анализа права и самой науки о праве. Исчезновение в учебниках упоминания о «сломе буржуазного государства», о социалистическом праве как новом, высшем типе права также объясняются спецификой аксиом науки права, указывают на то, что в отличие от аксиом точных наук, они не обладают вневременным свойством. 
Другое известное со студенческой скамьи утверждение транслирует идею о том, уже в ходе революции вместо эксплуататорского типа права возникло право, выражающее волю рабочего класса и руководимых им трудящихся масс.

В действительности, из анализа революционных событий и издаваемых в период революции актов логически выводится другая аксиома, которую можно сформулировать так: революционное законотворчество в первую очередь отражает интересы политической партии или группировки, находящейся у власти и направлена на удержание ее (их) у власти. В данном случае была бы уместна отсылка к вопросу о соотношении права и политики и дискуссии о правовой политике государства, но динамика революционных событий - этих фундаментальных превращений, осуществляемых, по словам Бермана, довольно быстро, в острой борьбе и «со страстью», не дает временного пространства ни для полноценного отражения посредством законодательства правопонимания, присущего новой власти, ни для выработки правовой политики.

В.В. Никулин справедливо отмечает, что в трактовке В.И. Ленина объективно присущая праву связь с политикой и государственной властью представляет собой новое, особое качественное явление; право и закон как его основное конкретное выражение рассматривается как неотъемлемое концентрированное орудие политики. Это утверждение еще более верно для периода революций, когда революционеры в сложнейших условиях дезориентации общества, экономического кризиса и гражданской войны, как правило сопровождающих революцию, должны удержаться у власти.

Вполне закономерно, что право подчиняется революционной целесообразности, поэтому первые акты закрепляют принципы действия нового правительства, мероприятия по переустройству общества и государства, и лишь в определенной степени по реализации самых насущных требований масс для создания хотя бы относительной стабилизации ситуации в стране, необходимой для проведения преобразований и для легитимации власти.

Так, во время Октябрьской революции в России в обращении к рабочим, солдатам и крестьянам, а также в декретах, принятых 26 октября 1917 г. было объявлено о низложении Временного правительства, переходе всей власти к Советам рабочих, солдатских и крестьянских депутатов, о мире, о земле, об армейских революционных комитетах. В первые послереволюционные дни были также утверждены основные положения закона о социализации земли, предусматривавшие передачу земли крестьянам по уравнительному принципу. Уже в первые дни советской власти был подготовлен декрет, 
предусматривающий упразднение всей старой судебной системы, а 22 ноября был принят Декрет о суде № 1.

В этом ясно прослеживается политическая направленность данного акта: судам предлагалось руководствоваться не законами и иными нормативными правовыми актами государства, а документами политических партий, которые имеют обязательное значение только для членов этих партий.. Для подавления политических противников советской власти 7 (20) декабря были образована Всероссийская чрезвычайная комиссия по борьбе с контрреволюцией и саботажем (ВЧК). Проявлением ярко выраженной политической целесообразности в революционном законодательстве говорит и тот факт, что почти полгода советская власть «не ломала четко отлаженную пенитенциарную систему царской России», без которой новой власти нельзя было существовать в отсутствии «сколько-нибудь ясных представлений об этой стороне деятельности».

Все выше перечисленные законодательно закрепленные мероприятия, подтверждают тезис о политической направленности нормативных правовых актов первых дней революции, а точнее о совпадении политики и права, что еще раз подтверждает несовпадении официальных аксиом правотворчества и действительного его содержания.

Таким образом и в этом случае мы должны принимать во внимание особенности правовых аксиом. Утверждение о том, что право, «рожденное революцией», выражало волю рабочего класса и руководимых им трудящихся масс представляет собой не что иное, как идеологическую аксиому советской науки права, которая истинна не сама по себе, а потому, что люди хотят в нее верить, хотят ее таковой видеть, потому, что в ней отображаются начала справедливости, хотя она лишь отчасти и соответствует действительности.

В заключение следует отметить, что рассуждения, связанные с двумя выше названными аксиомами, могут показаться неубедительными в плане «подбора» аксиоматических положений или даже существования аксиом правотворчества в целом. Может сформироваться мнение о справедливости высказывания В.И. Вернадского, утверждавшего, что только в некоторых частях научного мировоззрения содержатся обязательные для всех людей и необходимо признаваемые истины. Мы же полагаем, что аксиомы правотворчества существуют и как аксиомы права, и как аксиомы науки права, которые в силу своей специфики должны периодически подвергаться переоценки с точки зрения происходящих в правой науке изменений. 
1. Берман Г.Дж. Западная традиция права: эпоха формирования. / Пер. с англ. - 2-е изд. - М.: Изд-во МГУ: Издательская группа ИНФРА- М - НОРМА, 1998. - 624 с.

2. Долгих Ф.И. История отечественного государства и права: учеб. пособие / Ф.И. Долгих. - Москва: Московский финансово-промышленный университет «Синергия», 2012. - $336 \mathrm{c}$.

3. Згоржельская С.С. и др.: Учебное пособие для студентов непрерывного образования. М.: РАП, 2013. - $315 \mathrm{c}$.

4. Зяблова Т.Е., Масленников А. В. Правовые аксиомы / под ред. Мамчуна В. В.; Владим. юрид. ин-т федер. службы исполнения наказаний. - Владимир, 2009. - 135 с

5. История государства и права СССР. Ч 2. (Советский период): Учебник / Под ред. Г.С. Калинина, Г.В. Швекова. - 2-е изд., перераб. и доп. - М.: Юрид. лит., 1981. - 520 с.

6. Лопатин Л.М. Аксиомы философии // Лопатин Л.М. Аксиомы философии. Избр. ст. M., 1996. - 560 c.

7. Никулин В.В. Революционная теория права: мировоззренческие истоки большевистской концепции права // Вестник ТГУ. Серия: гуманитарные науки. Выпуск 8 (100). 2011. - С. 300-304. 